Jurnal Ilmu-Ilmu Peternakan 26 (1): 43 - 51

ISSN : 0852-3681

E-ISSN : 2443-0765

CFakultas Peternakan UB, http://jiip.ub.ac.id/

\title{
Jumlah Staphylococcus aureus dan kandungan nutrien susu akibat dipping puting menggunakan ekstrak daun belimbing wuluh (Averrhoa bilimbi Linn) pada sapi perah penderita mastitis subklinis
}

\author{
Patricia Romintan Aprilia, Sri Agus Bambang Santoso, Dian Wahyu Harjanti \\ Fakultas Peternakan dan Pertanian Universitas Diponegoro \\ Jl. drh. R. Soejono Koesoemowardojo-Tembalang, Semarang Kode Pos 50275 \\ dianharjanti@undip.ac.id
}

\begin{abstract}
The aim of the experiment was to examine the influence of Averrhoa bilimbi leaves extract as an antiseptic for teat dipping in dairy cattle on the number of Staphylococcus aureus and milk nutrients. A total of 16 subclinical mastitic cows were used in a completely randomized Split in Time Design with 4 treatments and 4 replications. Teat dipping was conducted everyday after morning and evening milking for 9 days. The main plot was the different antiseptic: antiseptic solution containing 1\%, 3\% and 5\% of Averrhoa bilimbi leaves extract (T1, T3 and T5 respectively) and povidone iodine $(\mathrm{K}+)$. The sub plot was the duration of teat dipping, in which the milk samples were taken at before treatment (H0) and 3 day, 6 day and 9 day of the treatment (H3, H6 and H9, respectively). The result showed no interaction between the different antiseptic and the duration of teat dipping. The number of Staphylococcus aureus in milk was reduced significantly $(\mathrm{P}<0.01)$ from $\mathrm{H0}\left(5.26 \times 10^{3} \mathrm{CFU} / \mathrm{ml}\right)$ to $\mathrm{H} 9\left(0.09 \times 10^{3} \mathrm{CFU} / \mathrm{ml}\right)$. Moreover, the contents of protein, lactose and fat were increased significantly $(\mathrm{P}<0.01)$ with teat dipping treatment for 9 days. In conclusion, Averrhoa bilimbi leaves extract could be used as a natural teat dip antiseptic to prevent Staphylococcus aureus infection and to ensure a better milk quality.
\end{abstract}

Keywords: Averrhoa bilimbi leaves, antiseptic, Staphylococcus aureus, milk nutrients

\section{PENDAHULUAN}

Susu merupakan salah satu produk peternakan yang memiliki nilai nutrisi yang tinggi. Namun rendahnya higienitas di peternakan menyebabkan produk peternakan ini seringkali dicemari oleh bakteri. Salah satu bakteri cemaran susu adalah Staphylococcus aureus. Kontaminasi Staphylococcus aureus dalam susu tidak menyebabkan perubahan fisik susu, sehingga seringkali keberadaanya tidak disadari konsumen. Standar Nasional Indonesia (SNI) tahun 2011 menetapkan batas maksimum cemaran Staphylococcus aureus pada susu sapi segar adalah $1 \mathrm{x}$ $10^{2} \mathrm{cfu} / \mathrm{ml}$. Penelitian Darmansyah (2011) melaporkan bahwa rataan jumlah Staphylococcus aureus pada sampel susu di Kabupaten Bogor sangat tinggi, yaitu $1,2 \times 10^{5} \mathrm{cfu} / \mathrm{ml}$. Selain dapat mencemari susu, bakteri Staphylococcus aureus merupakan bakteri patogen penyebab peradangan pada ambing atau mastitis. Infeksi mastitis diawali dari kondisi peternakan yang tidak higienis sehingga mendukung perkembangan bakteri Staphylococcus aureus.

Dipping puting merupakan salah satu cara yang dapat dilakukan untuk 
meningkatkan higienitas. Dipping puting adalah kegiatan pencelupan puting dengan menggunakan antiseptik agar bakteri di sekitar puting tidak masuk kedalam ambing. Salah satu antiseptik yang sering digunakan sebagai bahan dipping adalah povidone iodine. Povidone iodine merupakan antispetik kimia yang mampu membunuh bakteri dalam waktu 3-5 menit, namun povidone iodine mempunyai beberapa kekurangan yaitu menyebabkan efek rasa terbakar, nyeri, gatal dan kemerahan bahkan meninggalkan residu kimia pada susu. Oleh karena itu perlu adanya inovasi dalam menangani jumlah cemaran bakteri pada susu tanpa menimbulkan residu pada susu. Salah satu langkah yang dapat dilakukan adalah dengan menggunakan antiseptik herbal.

Daun belimbing wuluh merupakan salah satu tanaman herbal lokal yang mengandung senyawa antibakteri dan sangat mudah ditemukan Daun belimbing wuluh mengandung zat-zat aktif yang dapat menghambat pertumbuhan bakteri atau disebut zat antiseptik sehingga sering dijadikan bahan obat. Zat-zat aktif yang terkandung dalam daun belimbing wuluh adalah flavonoid, saponin, dan tannin (Hayati, dkk, 2010). Pemanfaatan daun belimbig wuluh sebagai bahan dipping belum ditemukan, sehingga perlu dilakukan pengujian penggunaan daun belimbing wuluh sebagai bahan dipping. Berdasarkan uraian diatas, maka perlu dilakukan penelitian mengenai penggunaan ekstrak daun belimbing wuluh guna menurunkan jumlah bakteri Staphylococcus aureus dan mempertahankan nutrisi susu.

\section{MATERI DAN METODE}

Penelitian ini dilaksanakan pada bulan November - Desember 2015 di UPTD Mulyorejo Tengaran, Salatiga, Jawa Tengah. Penelitian ini menggunakan sapi perah sebanyak 16 ekor dengan rata-rata masa laktasi bulan ke-2 dan ke-3.

\section{Materi penelitian}

Materi yang digunakan pada proses pembuatan ekstrak adalah bejana maserasi, sendok pengaduk, kertas saring, Vacuum Rotary Evaporator, waterbath, cawan porselin, simplisia daun belimbing wuluh dan etanol $70 \%$. Materi yang digunakan pada metode dipping dan pengambilan sampel adalah botol dipping, botol susu, cooling box, alat tulis, aquades dan povidone iodine. Materi yang digunakan pada uji Staphylococcus aureus dan uji kandungan susu adalah cawan petri, inkubator, jarum ose, colony counter, lactoscan, media selektif Baird Parker Agar (BPA), Brain Heart Infusion Broth (BHIB), Tryptic Soy Agar (TSA), koagulase plasma kelinci dengan Ethylene Diamine Tetra Acetic Acid (EDTA) 0,1\%, Buffer Pepton Water (BPW) 0,1\% dan egg yolk telltunile.

\section{Metode}

Metode penelitian berupa dipping putting menggunakan antiseptic Ekstrak Daun Belimbing Wuluh (EDBW) dengan konsentrasi yang berbeda selama 9 hari. Dipping puting dilakukan setelah akhir pemerahan baik pagi dan sore hari dengan lama dipping 10 detik. Enam belas ekor sapi perah laktasi diacak menjadi 4 perlakuan dipping puting. Perlakuan dipping yang dilakukan adalah :

$$
\begin{aligned}
\mathrm{T} 0= & \text { Dipping dengan povidone iodine } \\
& (10 \mathrm{ml}+90 \mathrm{ml} \text { aquades }) \\
\mathrm{T} 1= & 1 \%(1 \mathrm{ml} \mathrm{EDBW}+99 \mathrm{ml} \\
& \text { aquades }) \\
\mathrm{T} 3= & 3 \%(3 \mathrm{ml} \mathrm{EDBW}+97 \mathrm{ml} \\
& \begin{array}{l}
\text { aquades }) \\
\mathrm{T} 5=
\end{array} \\
& 5 \%(5 \mathrm{ml} \mathrm{EDBW}+95 \mathrm{ml} \\
& \text { aquades })
\end{aligned}
$$


Sebagai perlakuan tambahan, dilakukan pengambilan sampel susu dengan waktu yang berbeda yaitu hari ke- $0,3,6$, dan 9. Pengambilan sampel susu dilakukan pada pemerahan pagi. Sampel susu yang diambil adalah susu hasil pemerahan setelah pancaran susu ketiga. Sampel susu ditampung ke dalam botol kaca steril yang sudah diberi label dan dimasukkan kedalam kotak pendingin untuk dilakukan pengujian sampel. Pada sampel dilakukan pengujian sesuai dengan parameter yaitu Staphlococcus aureus dan kandungan nutrisi susu.

\section{Prosedur penelitian}

\section{Ekstraksi daun belimbing wuluh (Averrhoa bilimbi L)}

Simplisia daun belimbing sebanyak 300 g direndam dengan 5 liter etanol $70 \%$ dalam bejana maserasi dan diaduk selama 30 menit kemudian didiamkan selama 24 jam. Setelah 24 jam dilakukan penyaringan sebanyak 2 kali hingga diperoleh filtrat hasil penyaringan. Filtrat kemudian diuapkan dengan Vacuum Rotary Evaporator dalam pemanas waterbath dengan suhu $70^{\circ} \mathrm{C}$. Ekstrak kental hasil penguapan dituang kedalam cawan porselin lalu dipanaskan dengan waterbath pada suhu $70{ }^{\circ} \mathrm{C}$ sambil terus diaduk. Hasil ekstrak yang didapatkan seberat 43,86 g.

\section{Perhitungan jumlah Staphylococus aureus dalam susu}

Berdasarkan SNI

mengenai metode pengujian cemaran mikroba dalam daging, telur dan susu, serta hasil olahannya, pengujian jumlah Staphylococcus aureus menggunakan metode hitung cawan secara sebar pada permukaan media. Sampel susu sebanyak $1 \mathrm{ml}$ dimasukkan kedalam 9 $\mathrm{ml}$ larutan BPW 0,1\% (pengenceran 10${ }^{1}$ ), selanjutnya dilakukan pengenceran hingga $10^{-4}$. Pengenceran $10^{-2}, 10^{-3}, 10^{-4}$ diinokulasi sebanyak $1 \mathrm{ml}$ pada cawan petri. Pada tiap cawan petri dituangkan media selektif BPA (Baird Parker Agar) yang memiliki suhu $45^{\circ} \mathrm{C}$ yang telah ditambahkan egg yolk telltunile sebanyak $15 \mathrm{ml}$ kemudian dihomogenkan dan didiamkan hingga padat. Cawan petri yang sudah padat dibalik dan diinkubasi pada suhu $35^{\circ} \mathrm{C}$ selama 48 jam. Cawan petri yang mengandung koloni 20-200 Staphylococcus aureus dipilih dan diidentifikasi sesuai dengan ciri-ciri koloni Staphylococcus aureus. Ciri koloni khas Staphylococcus aureus bulat, licin, halus, konveks, basah, berdiameter 2-3 cm, berwarna abu-abu sampai hitam pekat, dikelilingi oleh zona opak (opaque zone), dengan zona luar yang jelas (clear zone). Jumlah masing-masing koloni yang sesuai dengan ciri seperti diatas dicatat dan dilanjutkan dengan uji identifikasi.

Pada uji identifikasi, dilakukan uji pengecatan gram dan uji koagulase. Uji pengecatan dilakukan dengan mengambil koloni dari masing-masing cawan petri dan dilakukan pengecatan gram. Pada hasil pengecatan gram, bakteri Staphylococcus aureus akan terlihat berwarna ungu (gram positif), berbentuk kokus dan bergerombol seperti anggur dan dilanjutkan dengan uji koagulase. Pada uji koagulase, satu atau lebih koloni pada cawan petri yang diduga Staphylococcus aureus dimasukkan kedalam 0,2 ml BHIB (Brain Heart Infusion Broth) dan dihomogenkan, lalu satu jarum ose penuh suspensi dari BHIB diambil untuk digoreskan pada agar miring TSA (Tryptic Soy Agar) dan diinkubasi pada suhu $35{ }^{\circ} \mathrm{C}$ selama 24 jam. Kemudian ditambahkan koagulase plasma kelinci (coagulase rabbit plasma) yang mengandung EDTA (Ethylene Diamine Tetra Acetic Acid) sebanyak 0,5 ml kedalam suspensi BHIB yang 
telah diinkubasi kemudian dihomogenkan dan diinkubasi kembali pada suhu $35^{\circ} \mathrm{C}$ selama 6 jam. Apabila ada penggumpalan maka hasil uji koagulase positif Staphylococcus aureus.

Perhitungan bakteri Staphylococcus aureus dilakukan dengan menghitung koloni dari cawan petri yang memiliki ciri koloni Staphylococcus aureus dan menunjukkan hasil uji koagulase positif, kemudian dikalikan dengan faktor pengencerannya.

\section{Uji kandungan nurisi susu}

Uji kualitas nutrisis susu dilakukan menggunakan lactoscan dengan cara memasukkan sampel susu kedalam beaker glass sebanyak $25 \mathrm{ml}$ dan me- letakkannya pada tempat analisis lactoscan. Menekan OK pada alat dan sampel akan tersedot masuk kedalam alat. Menekan tombol OK kembali dan data akan keluar pada layar monitor lactoscan, yaitu berupa data Lemak (Fat), Laktosa (Lactosa), dan Protein.

\section{HASIL DAN PEMBAHASAN}

\section{Pengaruh perlakuan terhadap jumlah bakteri Staphylococus aureus}

Hasil analisis jumlah bakteri Staphylococcus aureus akibat dipping dengan menggunakan Konsentrasi Antiseptik (A) yang berbeda dan Hari Pengambilan Sampel (B) yang berbeda ditampilkan pada Tabel 1.

Tabel 1. Rataan jumlah bakteri Staphlococus aureus pada susu

\begin{tabular}{cccccc}
\hline \multirow{2}{*}{ Perlakuan } & \multicolumn{4}{c}{ Hari } & \multirow{2}{*}{ Rataan } \\
\cline { 2 - 4 } & H0 & H3 & H6 & H9 & \\
\hline T0 & 3,08 & 0,46 & 0,19 & 0,08 & $0,95^{\mathrm{ns}}$ \\
T1 & 6,23 & 0,32 & 0,18 & 0,12 & $1,71^{\mathrm{ns}}$ \\
T3 & 5,55 & 0,57 & 0,28 & 0,07 & $1,61^{\mathrm{ns}}$ \\
T5 & 6,18 & 0,14 & 0,11 & 0,12 & $1,63^{\mathrm{ns}}$ \\
\hline Rataan & $5,26^{\mathrm{A}}$ & $0,37^{\mathrm{B}}$ & $0,19^{\mathrm{B}}$ & $0,09^{\mathrm{B}}$ & \\
\hline
\end{tabular}

Keterangan : Superkrip yang berbeda pada kolom yang sama menunjukkan perbedaan yang sangat nyata $(\mathrm{P}<0,01)$

Berdasarkan hasil analisis analisis ragam, tidak terdapat pengaruh nyata konsentrasi antiseptik dan interaksi konsentrasi antiseptik dengan hari pengambilan sampel $(\mathrm{P}>0,05)$ terhadap penurunan jumlah bakteri Staphylococus aureus. Rataan jumlah bakteri Staphylococus aureus akibat konsentrasi antiseptik yang berbeda tidak menunjukkan selisih yang signifikan. Namun demikian, faktor hari pengambilan sampel memberikan pengaruh sangat nyata $(\mathrm{P}<0,01)$ terhadap penurunan jumlah bakteri Staphylococus aureus. Rataan jumlah baktei Staphylococus aureus pada hari pen- gambilan sampel yang berbeda menunjukan selisih yang signifikan.

Pada penelitian ini, perlakuan dipping dengan konsentrasi antiseptik yang berbeda T0, T1, T3 dan T5 tidak berpengaruh nyata terhadap penurunan jumlah bakteri Staphylococcus aureus dalam susu. Rataan jumlah bakteri Stahylococcus aureus dengan konsentrasi berbeda dalam waktu 9 hari secara berturut turut adalah $0,95 \times 10^{3} \mathrm{cfu} / \mathrm{ml}$ (T0), $1,71 \times 10^{3}$ cfu/ml (T1), 1,61 x $10^{3}$ cfu/ml (T3), dan $1,63 \times 10^{3}$ cfu/ml (T5) $c f u / m l$. Selisih pada rataan bernilai tidak signifikan, sehingga dapat diketahui bahwa perlakuan T0 sebagai kontrol 
positif dengan larutan povidone iodine pada konsentrasi $10 \%$ jika dibandingkan dengan penggunaan ekstrak daun blimbing wuluh tidak menunjukkan reaksi yang berbeda dalam menurunkan jumlah bakteri Staphylococus aureus. Tidak terjadinya perbedaan antara ekstrak daun belimbing wuluh dan povidone iodine dalam menekan jumlah bakteri Staphylococus aureus diindikasikan karena komposisi zat aktif atau zat anti bakteri yang terdapat pada keduanya tidak berbeda atau memiliki kemampuan yang sama dalam menurunkan jumlah bakteri Staphylococus aureus tersebut. Cara kerja antimikroba yang terdapat dalam ekstrak daun belimbing wuluh antara lain dengan merusak dinding sel, merubah permeabilitas sel, menghambat kerja enzim, serta menghambat sintesis asam nukleat dan protein. Rahmawati, dkk (2015) menyatakan bahwa mekanisme daya hambat dimulai dari dari kandungan senyawa flavonoid yang menghambat metabolism energi pada bakteri sehingga respirasi oksigen terhambat dan bakteri kehilangan permeabilitas dinding sel. Saponin mendenaturasi protein dan merusak sitoplasma sel sehingga menurunkan tegangan permukaan dinding sel. Pada saat tegangan dinding sel terganggu, zat antimikroba tanin masuk kedalam sel bakteri dan mengkoagulasi protoplasma sel bakteri Stapylococcus aureus sehingga mengakibatkan pertumbuhan sel akan terhambat bahkan mati. Hal tersebut yang menyebabkan terjadinya penurunan jumlah baktei Staphylococcus aureus. Zat aktif dalam larutan povidone iodine yaitu kombinasi iodine dan polyvinylpyrrolidone. Povidone iodine yang berfungsi sebagai zat antimikroba yang mampu membunuh mikroorganisme, seperti bakteri, jamur, virus, protozoa, dan spora. Mekanisme antimikroba povidone iodine disebabkan oleh efek oksidasi yang kuat pada gugus asam amino, nukleotida, dan ikatan rangkap asam lemak tak jenuh mikroorganisme (Noor dkk., 2014).

Salah satu tahapan yang memungkinkan terjadinya cemaran yaitu saat lubang puting masih membuka pasca proses pemerahan, dimana masa tersebut menjadi masa yang sangat rentan terjadinya infeksi akibat masuknya bakteri kedalam ambing. Proses infeksi mastitis subklinis dimulai dengan masuknya mikroorganisme kedalam kelenjar melalui lubang puting yang terbuka setelah proses pemerahan. Mikroorganisme berkembang dalam puting dan menyebar ke alveoli dan menyebabkan kerusakan pada susu yang dihasilkan. Invasi mikroorganisme yang masuk kedalam ambing dan reaksi peradangan dapat merusak sel dalam ambing akibat dan menyebabkan produksi susu terganggu dan kualitasnya menurun (Holtenius, et al. 2004).

Penggunaan konsentrasi antiseptik daun belimbing wuluh yang berbeda dengan konsentrasi 1\%, 3\% dan 5\% menunjukkan perbedaan yang tidak nyata. Hasil penelitian ini berbeda dengan penelitian Mahpudin dkk. (2015) yang menggunakan ekstrak babadotan (Ageratum conyzoides) sebagai bahan dipping. Penggunaan ekstrak babadotan pada konsentrasi 5\% menunjukkan pengaruh yang nyata dalam menurunkan jumlah bakteri Staphylococcus aureus. Perbedaan hasil penelitian ini diduga karena kadar zat antiseptik flavonoid, saponin, dan tanin pada ekstrak daun belimbing wuluh lebih rendah dibandingkan dengan ekstrak babadotan, sehingga penggunaan konsentrasi ekstrak daun belimbing wuluh hingga kosentrasi maksimal 5\% pada penelitian ini tidak memberikan pengaruh yang sama dengan penelitian menggunakan ekstrak babadotan. Berdasarkan uraian diatas, maka dapat dipastikan penggunaan ekstrak belimbing 
wuluh dapat menjadi alternatif yang lebih alami dalam menurunkan jumlah bakteri staphylococus aureus atas larutan povidone iodine yang masih tersusun dari beberapa senyawa kimia. Adapun dosis yang direkomendasikan yaitu pada perlakuan T1 dengan dosis 1\%. Dalam penelitan ini penggunaan larutan eksrak daun belimbing wuluh pada perlakuan T3 (3\%) dan T5 (5\%) memiliki aksi yang sama dengan $\mathrm{T} 1$ (1\%), sehingga perlakuan T1 (1\%) lebih ekonomis jika diaplikasikan pada suatu usaha peternakan sapi perah.

Pada hari pengambilan sampel yang berbeda menunjukkan pengaruh nyata terhadap penurunan jumlah bakteri Staphylococus aureus. Rataan jumlah Staphylococcus aureus 5,26 x $10^{3}$ $c f u / \mathrm{ml}, 0,37 \times 10^{3} c f u / \mathrm{ml}, 0,19 \times 10^{3}$ cfu/ml dan $0,09 \times 10^{3}$ cfu/ml. Rataan jumlah bakteri Staphylococcus aureus menunjukkan penurunan signifikan. Hal ini membuktikan bahwa perlakuan dipping putting dengan konsentrasi yang berbeda yang dilakukan selama 9 hari dapat menurunkan jumlah Staphylococcus aureus hingga pada batas maksimal bakteri Staphylococcus aureus pada susu sesuai dengan standar pada H9 dengan rataan $0,09 \times 10^{3} \mathrm{cfu} / \mathrm{ml}$. Standar maksimal bakteri Staphylococus aureus pada susu sesuai dengan SNI yaitu $1 \times 10^{2}$ cfu/ml.

Pada hasil uji lanjut, penurunan signifikan terjadi pada pengambilan sampel pertama setelah dilakukannya perlakuan dipping H3. Penurunan jumlah bakteri pada $\mathrm{H6}$ dan $\mathrm{H} 9$ dinyatakan tidak berbeda dengan H3 pada uji lanjut. Pada sampel H0 rataan jumlah bakteri Staphylococcus aureus lebih tinggi, hal ini dikarenakan pengambilan sampel dilakukan pada hari ke- 0 sebelum perlakuan dipping. Kodisi ini menunjukkan bahwa perlunya kegiatan dipping pada akhir pemerahan dengan tujuan menekan jumlah cemaran bakteri yang dapat masuk kedalam ambing dan mencemari susu. Hal ini sesuai dengan pendapat Safangat dkk. (2014) bahwa terbukanya saluran susu pada puting setelah selesai pemerahan dapat mengakibatkan masuknya mikroorganime kedalam ambing, maka dari itu saat setelah akhir pemerahan perlu dilakukan dipping puting dengan menggunakan antiseptik untuk mencegah pertumbuhan dan membunuh mikrorganisme. Mikroorganisme berkembang dalam puting dan menyebar ke alveoli dan menyebabkan kerusakan pada susu yang dihasilkan. Mikroorganisme yang masuk kedalam ambing dapat merusak sel dalam ambing akibat invasi mikroorganisme dan reaksi peradangan dan menyebabkan produksi susu terganggu dan kualitas susu menurun (Holtenius, et al. 2004).

Kondisi ini dapat memberikan informasi mengenai lama kinerja zat aktif yang terdapat pada ekstrak daun blimbing wuluh dan povidone iodine dalam menekan jumlah bakteri Staphylococus aureus. Adapun waktu perlakuan dipping yang direkomendasikan yaitu selama 9 hari secara kontinyu. Kondisi ini sedikit lebih cepat jika dibandingkan dengan hasil penelitian Arimbi dan Sabdoningrum (2008) dimana perlakuan menggunakan daun sambiloto selama 7 hari tidak memberikan perbedaan yang nyata terhadap jumlah bakteri Staphylococcus aureus antara sebelum dan setelah dipping. Sehingga semakin lama perlakuan dipping semakin efektif dalam menurunkan jumlah bakteri Staphylococus aureus.

\section{Pengaruh perlakuan terhadap jum- lah bakteri Staphylococus aureus}

Hasil analisis kandungan protein, laktosa dan lemak susu akibat dipping dengan larutan antiseptik yang mengandung ekstrak daun belimbing wuluh disajikan pada Tabel 2, 3 dan 4. 
Tabel 2. Rataan kandungan protein susu

\begin{tabular}{crrrrl}
\hline \multirow{2}{*}{ Perlakuan } & \multicolumn{4}{c}{ Hari } & \multirow{2}{*}{ Rataan } \\
\cline { 2 - 4 } & H0 & H3 & H6 & H9 & \\
\hline T0 & 2,76 & 2,45 & 2,51 & 3,03 & $2,68^{\text {ns }}$ \\
T1 & 2,78 & 2,45 & 2,40 & 2,90 & $2,63^{\text {ns }}$ \\
T3 & 2,84 & 2,44 & 2,43 & 2,86 & $2,64^{\text {ns }}$ \\
T5 & 2,70 & 2,47 & 2,39 & 2,80 & $2,59^{\text {ns }}$ \\
\hline Rataan & $2,77^{\mathrm{A}}$ & $2,45^{\mathrm{B}}$ & $2,43^{\mathrm{B}}$ & $2,89^{\mathrm{C}}$ & \\
\hline
\end{tabular}

Keterangan : Superskrip yang berbeda pada kolom yang sama menunjukan perbedaan yang nyata $(\mathrm{P}<0,01)$

Tabel 3. Rataan kandungan laktosa susu

\begin{tabular}{crrrrr}
\hline \multirow{2}{*}{ Perlakuan } & \multicolumn{4}{c}{ Hari } & \multirow{2}{*}{ Rataan } \\
\cline { 2 - 4 } & H0 & H3 & H6 & H9 & \\
\hline T0 & 4,15 & 3,69 & 3,77 & 3,80 & $3,85^{\text {ns }}$ \\
T1 & 4,17 & 4,45 & 3,59 & 4,43 & $3,97^{\text {ns }}$ \\
T3 & 4,26 & 3,68 & 3,66 & 4,36 & $3,99^{\text {ns }}$ \\
T5 & 4,04 & 3,72 & 3,60 & 4,58 & $3,99^{\text {ns }}$ \\
\hline Rataan & $4,15^{\mathrm{B}}$ & $3,70^{\mathrm{C}}$ & $3,65^{\mathrm{C}}$ & $4,28^{\mathrm{A}}$ & \\
\hline
\end{tabular}

Keterangan : Superskrip yang berbeda pada kolom yang sama menunjukan perbedaan yang nyata $(\mathrm{P}<0,01)$

Tabel 4. Rataan kandungan lemak susu

\begin{tabular}{|c|c|c|c|c|c|}
\hline \multirow{2}{*}{ Perlakuan } & \multicolumn{4}{|c|}{ Hari } & \multirow{2}{*}{ Rataan } \\
\hline & $\mathrm{HO}$ & H3 & H6 & H9 & \\
\hline \multicolumn{6}{|c|}{--------------- (\%)--------------- } \\
\hline T0 & 2,95 & 4,52 & 5,98 & 5,12 & $4,46^{\mathrm{ns}}$ \\
\hline $\mathrm{T} 1$ & 2,88 & 4,49 & 5,27 & 4,19 & $4,21^{\mathrm{ns}}$ \\
\hline T3 & 3,64 & 4,34 & 5,42 & 3,98 & $4,34^{\mathrm{ns}}$ \\
\hline T5 & 1,85 & 4,12 & 5,43 & 5,36 & $4,19^{\mathrm{ns}}$ \\
\hline Rataan & $2,83^{\mathrm{D}}$ & $4,36^{\mathrm{C}}$ & $5,53^{A}$ & $4,66^{\mathrm{B}}$ & \\
\hline
\end{tabular}

Keterangan : Superskrip yang berbeda pada kolom yang sama menunjukan perbedaan yang nyata $(\mathrm{P}<0,01)$.

Berdasarkan analisis statistik, tidak terdapat pengaruh konsentrasi antiseptik dan interaksi antara konsentrasi antiseptik dengan hari pengambilan sampel $(\mathrm{P}>0,05)$ terhadap kandungan nutrisi susu. Namun, terdapat pengaruh yang signifikan $(\mathrm{P}<0,01)$ pada hari pengambilan sampel terhadap kandungan nutrisi susu. Kualitas susu merupakan kriteria terpenting dalam menentukan kesehatan dan kelayakan pasar susu. Pada penelitian ini, perlakuan konsentasi antiseptik T0, T1, T2 dan T3 menunjukkan hasil yang sama dalam kandungan protein, laktosa dan lemak susu, serta sesuai dengan standar untuk kualitas susu segar. Standar minimum kualitas susu segar di Indonesia memiliki persentase lemak susu 3\%, protein susu 2,8\%, dan laktosa susu 4\% (SNI, 2011). 
Hal ini membuktikan bahwa perlakuan dipping dengan antiseptik povidone iodine dan ekstrak daun belimbing wuluh memiliki kemampuan yang sama dalam menjaga kandungan nutrien susu.

Pada perlakuan hari pengambilan sampel menunjukkan adanya pengaruh terhadap kandungan nutrien susu. Berdasarkan hasil uji lanjut, data rataan protein susu pada Tabel 2 terjadi kenaikan kandungan protein susu dari 2,77\% (sebelum perlakuan teat dipping) menjadi 2,89\% pada hari ke-9 perlakuan teat dipping. Hasil serupa juga ditemukan pada kandungan laktosa dan lemak susu. Kandungan laktosa mengalami kenaikan yang sangat nyata $(\mathrm{P}<0,01)$ dari 4,15\% (sebelum perlakuan) menjadi 4,28\% pada hari ke-9 perlakuan teat dipping. Kandungan lemak juga mengalami peningkatan yang sangat nyata $(\mathrm{P}<0,01)$ dari $2,83 \%$ (sebelum perlakuan) menjadi $4,66 \%$ pada hari ke-9 perlakuan dipping puting.

Selain jumlah dan kualitas pakan, pemerahan dan penyakit pada sapi perah merupakan faktor yang juga berperan terhadap tinggi rendahnya kandungan nutrisi susu (Batavia, et al., 2007). Masuknya Staphylococcus aureus kedalam ambing dapat menyebabkan peradangan pada ambing dan berdampak merusak sel epitel dalam ambing sehingga sekresi komponen susu dapat terganggu dan menyebabkan kualitas susu menurun. Ruegg (2000) menyatakan bahwa semakin tinggi tingkat peradangan maka jumlah sel sekretoris yang mengalami kerusakan juga semakin tinggi.

Dipping puting merupakan salah satu cara yang dapat dilakukan untuk mencegah infeksi Staphylococcus aureus kedalam ambing. Proses infeksi patogen kedalam kelenjar melalui lubang puting yang terbuka setelah proses pemerahan. Mikroorganisme berkembang dalam puting dan menyebar ke alveoli dan menyebabkan kerusakan pada susu yang dihasilkan. Mikroorganisme yang masuk kedalam ambing dapat merusak sel dalam ambing akibat invasi mikroorganisme dan reaksi peradangan dan menyebabkan produksi susu terganggu dan kualitas susu menurun. Ditambahkan oleh Surjowardojo (2012) bahwa komponen susu dibentuk di kelenjar susu yang terdiri dari alveolus. Setiap alveolus terdiri dari sel epitel yang merupakan sel-sel sekresi susu. Setelah mikroorganisme berhasil masuk kedalam kelenjar, dalam waktu singkat akan membentuk koloni dan menyebar ke lobuli dan alveoli dan menyebabkan perubahan komposisi susu yang ada di dalam kelenjar susu termasuk adanya penurunan kadar lemak, protein dan laktosa pada susu.

Pada penelitian ini perlakuan dipping dengan konsentrasi antiseptik yang berbeda selama 9 hari dapat menurunkan jumlah bakteri penyebab peradangan ambing yakni Staphylococcus aureus (lihat Tabel 1), sehingga kondisi ini seharusnya diiringi dengan perbaikan nilai kandungan nutrisi susu. Pada hasil rataan kandungan protein, lemak dan laktosa H0 (sebelum perlakuan dipping) secara signifikan lebih tinggi dibanding dengan H3, H6, dan H9 (sesudah dipping). Hal ini diduga terdapat faktor lain yang berpengaruh terhadap nutrisi susu pada saat perlakuan, sehingga kandungan susu setelah perlakuan menurun.

\section{KESIMPULAN}

Berdasarkan hasil penelitian dapat disimpulkan bahwa ekstrak daun belimbing wuluh memiliki kemampuan yang sama dengan antiseptik kimia povidone iodine dalam menurunkan jumlah bakteri Staphylococcus aureus dan menjaga kualitas nutrien susu. Penggunaan ekstrak daun belimbing wuluh dengan konsentrasi $1 \%$ dapat 
digunakan sebagai bahan dipping pengganti antiseptik kimia dengan jangka waktu penggunaan 9 hari secara kontinyu.

\section{DAFTAR PUSTAKA}

Arimbi dan E. K. Sabdoningrum. 2008. Aplikasi daun sambiloto sebagai bahan aktif dipping dalam program kontrol mastitis pada sapi perah. Research report GDLHUB / 2008-arimbi-6931.

Batavia, R. A., S. Asri, H. Naebzadeh. 2007. The effect of subclinical mastitis on milk composition in dairy cows. Iranian Journal of Veterinary Research 8 (3) : 205 $-211$.

Darmansah, I. 2011. Penilaian kualitas susu sapi berdasarkan jumlah total mikroorganisme, Escherichia coli dan Staphylococcus aureus di Kabupaten Bogor, Cianjur, Bandung, Sumedang, Dan Tasikmalaya, Provinsi Jawa Barat. Institut Pertanian Bogor, Bogor.

(http://repository.ipb.ac.id/handl e/123456789/51862) diakses pada Maret 2016.

Hayati, E. K., A.G. Fasyah, dan L. Sa'adah. 2010. Fraksinasi dan identifikasi senyawa tanin pada daun belimbing wuluh (Averrhoa Bilimbi Linn). Jurnal Kimia 4 (2):193-200.

Holtenius K, W. K. Persson, G. B. Essén, S. C. Hallén. 2004. Metabolic parameters and blood leukocyte profiles in cows from herds with high or low mastitis incidence. Vet. J. 168 (1) :6573.

Mahpudin, A. Farrasfaza, A. A. P. Ulya, A. Ramandhani, W. A. Harjanti, dan D. W. Harjanti. 2015. Green antiseptic ekstrak babadotan
(Ageratum conyzoides) untuk dipping puting sapi perah yang aman, ekonomis, dan ramah lingkungan. Fakultas Peternakan dan ertania, Universitas Diponegoro. (Laporan Penelitian).

Noor, M. A dan M. L. Apriasari. 2014. Efektivitas antibakteri ekstrak metanol batang pisang Mauli (Musa acuminata) dan povidone iodine $10 \%$ terhadap Streptococcus mutans. Jurnal Persatuan Dokter Gigi Indonesia 63 (3) : 73 -83.

Rahmawati, D., P. Surjowardojo, dan Sarwiyono. 2015. Daya hambat ekstrak daun beluntas (Pluchea indica $L$.) dengan pelarut methanol terhadap pertumbuhan bakteri Staphylococcus aureus dan Eschericia coli penyebab mastitis pada sapi perah. Fakultas Peternakan. Universitas Brawijaya Malang. (http://fapet.ub.ac.id/) diakses pada April 2016)

Ruegg, P. L. 2002. Milk secretion and quality standards. University of Wisconcins. Madison. USA.

Safangat, A., Sarwiyono, dan P. Surjowardojo. 2014. Pengaruh penggunaan jus daun kelor (Moringa oleifera) untuk teat dipping terhadap kejadian mastitis sub klinis sapi perah FH laktasi. Fakultas Peternakan Universitas Brawijaya. Malang.

SNI. 2008. Metode pengujian cemaran mikroba dalam daging, susu, telur dan olahannya. BSN. Jakarta.

SNI. 2011. Susu segar-bagian 1: Sapi, BSN. Jakarta.

Surjowardojo, P. 2012. Penampilan kandungan protein dan kadar lemak susu pada sapi perah mastitis Friesian Holstein. J.Exp. Life Sci. 2 (1) : 42-48. 